\title{
INDONESIA RAILWAYS STRATEGY TO MAXIMIZE FREIGHT TRAIN
}

\author{
Alya Dainida ${ }^{1}$, Rizka Arlia Kartika ${ }^{2}$, Masjraul Hidajat $^{3}$,RatnaSuminar ${ }^{4}$ \\ 1. STMT Trisakti, 2. STMT Trisakti, 3. STMT Trisakti, 4.STMT Trisakti \\ Correspondence author: alyadainida@yahoo.com
}

\begin{abstract}
Trains can only carry cargo from one station to other stations. To arrive at the destination, the cargo still needs to be carried by other mode of transportation. About $80 \%$ of transportation in Java is dominated by roadway transportation by far. Many business doers prefer using trucks to trains because ofthe handling andthe accessibility. The purpose of this research is to find a proper strategy to be proposed to PT. KAI to maximize the usage of freight trains in Indonesia through SWOT analysis. Those strategies are market penetration, product development, force sustentation and opportunities utilization.

Keywords: strategy, freight train, railway, transportation, swot analysis
\end{abstract}

\section{Introduction}

Transportation is a device used to travel goods or people from one place to another in which the existence of the transportation depends on the infrastructure provided (Kadarisman, Gunawan, \& Ismiyati, 2016). A train, one of modern transportation, which supports the growth of cargo dispatcher, is a rapid mass transportation that is very effective and efficient because trains have their own tracks that they cannot be interfered by other transportations (Yudhistira \& Agushinta, 2015)

Freight train is expected to have an important role in transportation (Toletti, De Martinis, \& Weidmann, 2015). Freight train has become one of the alternative service preferences for customers. Therefore, PT. KAI supposed to offer a proper service to the customers (Islam \& Mortimer, 2017). Compared to other land transportations, freight train should offer a better security and efficiency(Le \& Jaumard, 2017).

The use of freight train to move logistics is still limited in Indonesia. Logistics deals with goods movement, delivery, service and information (Lummus, Krumwiede, \& Vokurka, 2001). Freight trains can only travel from one station to another. To arrive at train station or from train station to the destination, goods needs other mode of transportation. Since trains only 
have access from one station to another, double handling or double loading and unloading frequently occurs. Meanwhile, using freight trains to move cargos is more secure and assessable in terms of time. About $80 \%$ of transportation in Java Island is dominated by roadways mode of transportation recently. Most business doers prefer using trucks to trains to send cargos. This is because of the handling and accessibility process (Rifni \& Prasetya, 2016). There are some constrains usually occur in usingroadways transportation, such as, traffic congestion, uncertain time, less security, and infrastructure development. Using freight train in cargo shipping is expected to be able to minimize those constrains.

By SWOT analysis, this study focused on the strategies proposed to those in charge in maximizing the use of freight trains. The writers use questionnaire as main data resource and statistics data taken from PT. KAI annual report as secondary data.

\section{Method}

This research used SWOT analysis. SWOT analysis is used to analyze the strength and weakness of a company, the development opportunity, and the outsider threat (Gretzky, 2010). According to Kunci and Rangkuti (2004), SWOT is important to analyze the external and internal factors of a company. Internal factors include the strength and weaknesses of a company, while the external factors include the opportunity and the threat. Another definition of SWOT is atechnique of analysis to find the best way to reach virtuous improvement in the future. The process includes the identification of strength and weakness of a company, the market opportunity and threat (Skills, 2013).

The writers used a method of library research in collecting data and formulizing the concept and theory as the basic research. The writers also did some observation through the annual report of PT. KAI for the period of 2009 - 2016. The annual reports were taken from PT. KAI official website. Moreover, the writers used questionnaire, which was distributed to the logistics professionals. 


\section{Discussion and Result}

Strengths:

1. Train has been the most preferable mass mode of transportation for the society.

2. Train is a speedy transportation.

One of the strengths of a train is that it has its own railway track. As a result, it can travel much faster and there would not be any constraints like traffic congestion as in roadways transportation.

3. Freight trains provide more secure service for the cargos they carry. Railway or train carries not only people, but also goods or cargo that needs additional security. Therefore, Freight trains become preferable option since they have their own railway track and provide more secure assurance.

4. Railway stations provide a bulky area.

Freight train stations generally have bulky areas for cargos' loading and unloading and for the coaches' train setting as in Indonesia. For example, Jakarta Gudang freight train stationsandPasoso station in Tanjung Priok.

5. Trains have fixed schedule.

The fixed schedule of freight trains will facilitate the passengers in recognizing the departure and destination time.

Weaknesses:

1. There are no door-to-door facilities for sending cargos.

Almost all freight trains can merely move goods or cargos from one station to another. They cannot do the door-to-door delivery. Other mode of transportation is still required to send the goods to its final destination.

2. The facilities for loading and unloading are restricted. This is one of the weaknesses of freight trains. Not all freight train stations provide such complete facilities for loading and unloading.

3. There has been an inadequate frequency for freight trains. 
The number of trains operated in one track depends on the track's capacity. When the track's capacity is overwhelmed, then other trains would not be able to use it.

4. The ineffective use of coaches

Most coaches are only used for one type of cargo. For example, after the arrival, coaches used to carry coals will return empty and they are not used to carry other cargos. Similar things happened to the coaches carry fuel and fertilizer.

\section{Opportunities:}

1. The high economic growth in Indonesia affects to the excessive demands towards mass transportation, especially those from industry. Industrial business requires an effective mass transportation to carry the raw materials and the products of the industry.

The high economic growth gives opportunity for freight trains' company in Indonesia to improve the transportation. The increase number of coaches from 2009 to 2016 has developed the transport capacity that will contribute to the raise of the company's performance and income.

2. The freight station locations are near to the industries.

If the location of the stations is in nearby industries, it will facilitate the door-to-door service system since the transportation movement will also occur in the industrial areas.

3. The demand of goods shipping services is excessive.

The numerous growth of e-commerce in this modern era causes to the increasing demands of goods shipping services in the society. More people are well-off shopping through on-line stores nowadays that affects to the shipping services. Since those goods bought by online customers are delivered through shipping services, freight trains' company should take this opportunity to develop the shipping services. 
4. Some loyal customers always use railways' service.

Freight trains' company has the opportunity to improve the service because there are some loyal customers who always use the service. For example, gasolines, coal, cement and mineral water haulage always use freight trains.

Threats:

1. Truck is more flexible for shipping.

The flexibility of trucks in shipping is a threat for freight trains. Truck can operate in flexible time, while freight trains have definite time operation schedule.

2. Shipping tariff for truck is lower than freight train.

Tariff is one of crucial point in shipping. It is reasonable if a company set a tariff for shipping. The inexpensive tariff for shipping by truck becomes a threat for freight trains.

3. Truck does not require double handling that makes it easier to handle the shipping.

Another threat is that truck does not require double handling that it enables truck to give door-to-door services. Meanwhile, freight trains require other mode of transportation to deliver goods or cargos to the final destination.

4. The development of highways recently facilitates truck to reach its destination faster.

The development of highways recently becomes a threat for freight trains since it will make truck's travel time more efficient. Therefore, truck will be more preferable for many companies.

The writers used SWOT diagram, matrix IE (internal-external) and SWOT analysis to find the best solution of the problems of trains'industryin Indonesia (PT. KAI). From the questionnaires processing data, the writers made IFAS and EFAS tables where the results of this study found that the total strength was 1,89 , total weaknesses was 1,37 , opportunity was 1,75 
and threat was 1,62. The total points for strength and weakness were 3,26 and total points of opportunity and threat were 3,37 .

\section{SWOT DIAGRAM}

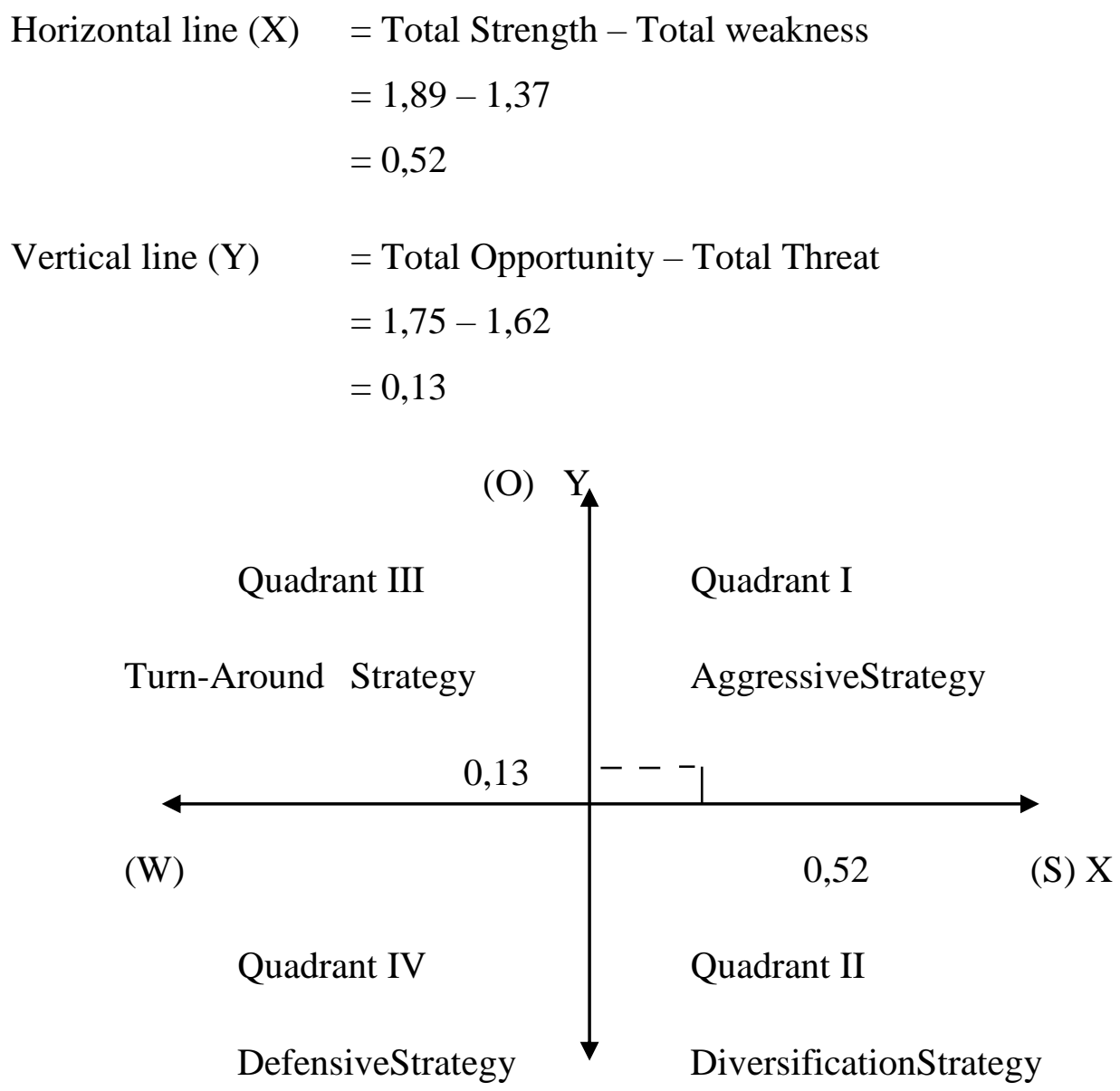

(T)

Figure 1.

Source: writers processing data

Based on the SWOT diagram, company is in Quadrant 1, which is aggressive strategy with internal strength of $(0,52)$ and the opportunity around the external area is $(0,13)$. 
MATRIX IE

Table 1.

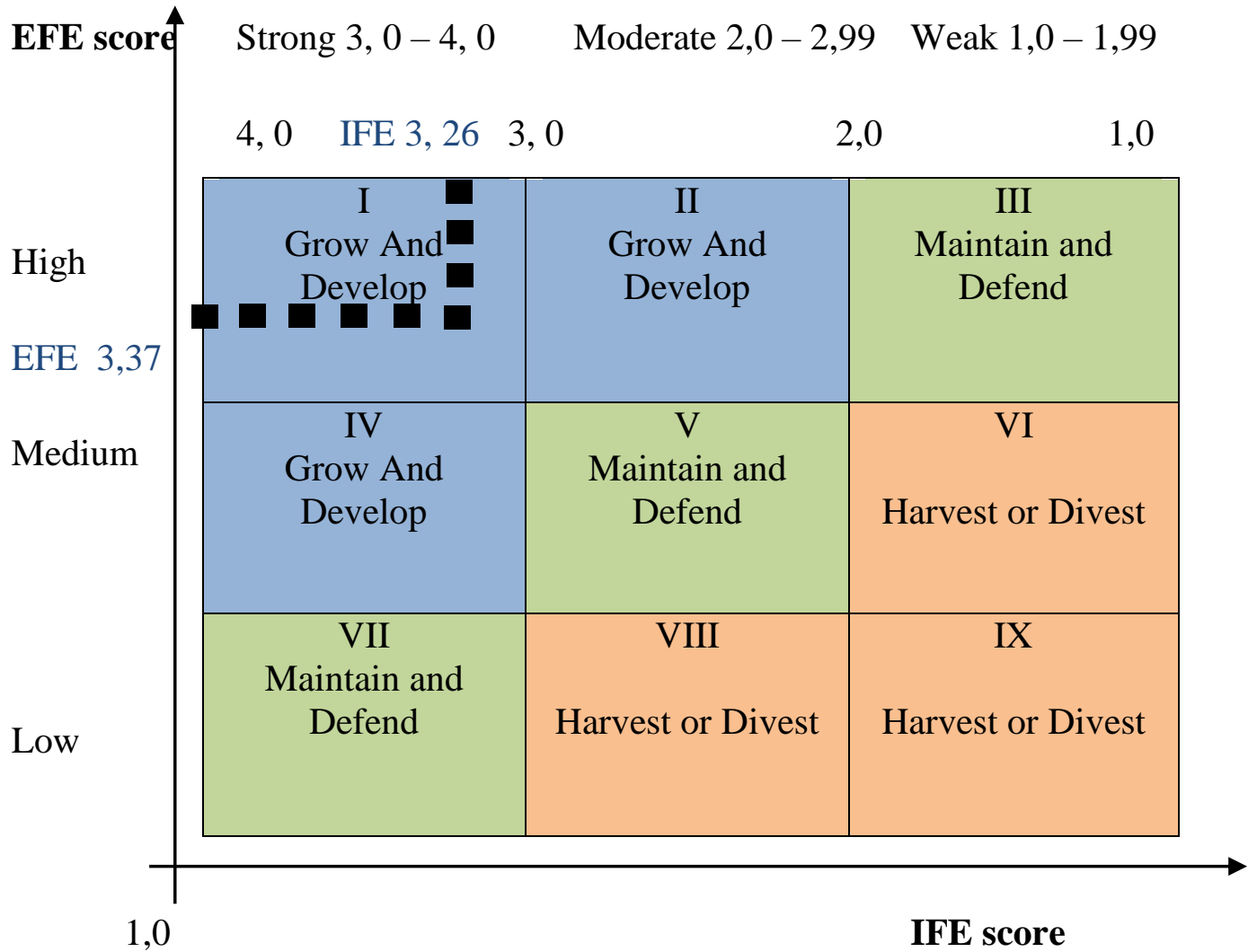

According to Matrix IE, the company is in column 1, which growing and developing.

SWOT ANALYSIS

Table 2.

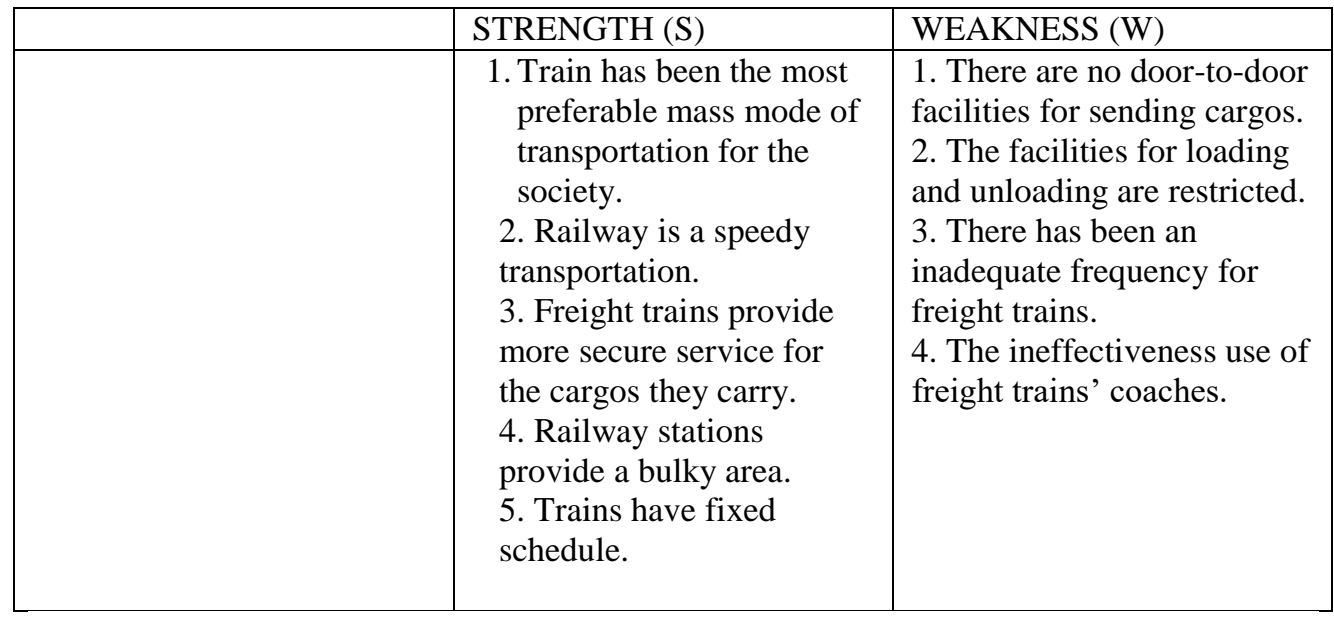


Table 2, cont

\begin{tabular}{|c|c|c|}
\hline OPPORTUNITY (O) & S-O STRATEGY & W-O STRATEGY \\
\hline $\begin{array}{l}\text { 1. The high economic } \\
\text { growth in Indonesia affects } \\
\text { to the excessive demands } \\
\text { towards mass transportation, } \\
\text { especially those from } \\
\text { industry. } \\
\text { 2. The freight station } \\
\text { locations are near to the } \\
\text { industries. } \\
\text { 3. The demand of goods } \\
\text { shipping services is } \\
\text { excessive. } \\
\text { 4. Some loyal customers } \\
\text { always use railways' } \\
\text { service. }\end{array}$ & $\begin{array}{l}\text { 1. Maintain the quality, } \\
\text { increase service quality and } \\
\text { keep the customers' trust. } \\
\text { (S1, S3, O1, O3, O4) } \\
\text { 2. Build new stations close } \\
\text { to industrial areas. (S4, O2) } \\
\text { 3. Develop freight train } \\
\text { stations to increase the } \\
\text { capacity. } \\
(\mathrm{S} 4, \mathrm{O} 2, \mathrm{O} 3, \mathrm{O} 4)\end{array}$ & $\begin{array}{l}\text { 1. Create more freight trains } \\
\text { for logistics needs to } \\
\text { increase the market by } \\
\text { providing door-to-door } \\
\text { services. (W1, O1, O3) } \\
\text { 2. Develop loading and } \\
\text { unloading facilities to } \\
\text { increase the capacity of } \\
\text { loading and unloading. (W2, } \\
\text { O2) } \\
\text { 3. Provide more coaches to } \\
\text { increase the capacity. } \\
\text { (W3, O1, O3) } \\
4 . \text { Replace the coaches with } \\
\text { flat carriageusing container } \\
\text { or pallet. } \\
\text { (W4, O2) }\end{array}$ \\
\hline THREAT (T) & S-T STRATEGY & W-T STRATEGY \\
\hline $\begin{array}{l}\text { 1. Truck is more flexible for } \\
\text { shipping. } \\
\text { 2. Shipping tariff for truck is } \\
\text { lower than freight train. } \\
\text { 3. Truck does not require } \\
\text { double handling that makes } \\
\text { it easier to handle the } \\
\text { shipping. } \\
\text { 4. The development of } \\
\text { highways recently facilitates } \\
\text { truck to reach its destination } \\
\text { faster. }\end{array}$ & $\begin{array}{l}\text { 1. Maintain the trains' } \\
\text { performance. Keep } \\
\text { providing good services for } \\
\text { the train users with } \\
\text { punctuality, guarantee of } \\
\text { security, and providing good } \\
\text { facilities, so that the } \\
\text { customers will not turn to } \\
\text { other mode of } \\
\text { transportation. } \\
(\mathrm{S} 1, \mathrm{~S} 2, \mathrm{~S} 3, \mathrm{~S} 4, \mathrm{~T} 3, \mathrm{~T} 4)\end{array}$ & $\begin{array}{l}\text { Improve the facilities } \\
\text { such as, double tracking, } \\
\text { to increase the tracks } \\
\text { capacity and trains } \\
\text { occurrences. } \\
\text { (W3, T4) }\end{array}$ \\
\hline
\end{tabular}

Based on the three matrix results, PT. KAI must do market penetration, develop the products, maintain the strengths and maximize the opportunities.

\section{Market Penetration}

This is a strategy to improve target market by developing and increasing the facilities of loading and unloading, increasing the number of freight coaches, enhancing freight trains' performance, and increasing the facilities of double tracking so that the train's tracks capacity is also increased. Other market penetration strategies are creating better marketing and promotion either through printed or electronics media. 
2. Products development

Improving products and services are parts of strategies to improve the sales. PT. KAI may build a sister company that specially deals withgoods or cargo shipping and delivers door-to-door services, by providing other mode of transportations like trucks in different sizes, container yard to improve crates transport, and the facilities for loading and unloading.The development of the supporting infrastructure such as, loading and unloading terminal will support the expansion offreight train transportation in Indonesia (Rifni \& Prasetya, 2016), therefore, it is secure to carry the cargos into the coaches(S, 2016).

\section{Conclusion}

PT. KAI is capable to decrease the threats since there are some big opportunities and strengths to maximize its potency. Company has strengths and weaknesses that can strengthen its position. Moreover, it may also benefit the opportunities and minimize the outsider threats. A strategy that the company can apply is building a sister company dealt with logistics train. The sister company is built to increase the market by providing doorto-door services, improving freight train stations and completing the loading and unloading facilities. The strategies application is in order to increase the loading - unloading and freight trains' capacity, even the infrastructure of double tracking to enlarge trains tracks capacityso that the trains' frequency willalsoincrease. Besides, providing more coaches for goods or cargos and delivering trucks to move goods (from the initial place to station or from the station to the final destination) andsupporting the coaches with container yards are further strategies.

\section{References}

Gretzky, W. (2010). STRATEGIC PLANNING AND SWOT ANALYSIS, 91-97.

Islam, D. M. Z., \& Mortimer, P. N. (2017). Longer, faster and heavier 
freight trains. Benchmarking: An International Journal, 24(4), 9941012. https://doi.org/10.1108/BIJ-05-2015-0051

Kadarisman, M., Gunawan, A., \& Ismiyati, I. (2016). Kebijakan Manajemen Transportasi Darat dan Dampaknya Terhadap Perekonomian Masyarakat di Kota Depok. Jurnal Manajemen Transportasi \& Logistik, 3(1). Retrieved from http://www.ejournal.stmttrisakti.ac.id/index.php/JMTRANSLOG/article/view/72

Kunci, K., \& Rangkuti, F. (2004). Zuhrotun Nisak.

Le, T. H., \& Jaumard, B. (2017). Freight Train Scheduling with Minimum Energy Consumption, 1(3), 501-510. https://doi.org/10.2495/TDI-V1N3-501-510

Lummus, R. R., Krumwiede, D. W., \& Vokurka, R. J. (2001). The relationship of logistics to supply chain management: developing a common industry definition, 426-431.

Rifni, M., \& Prasetya, O. (2016). Kereta Api Logistik, 405-419.

S, T. I. H. (2016). MULTIMODA DALAM MEWUJUDKAN VISI LOGISTIK INDONESIA 2025, 69-84.

Skills, S. (2013). SWOT Analysis.

Toletti, A., De Martinis, V., \& Weidmann, U. (2015). What about train length and energy efficiency of freight trains in rescheduling models? Transportation Research Procedia, 10(July), 584-594. https://doi.org/10.1016/j.trpro.2015.09.012

Yudhistira, G., \& Agushinta, L. (2015). Transportation System in Japan : A Literature Study, 2(3), 333-352. 